\title{
ОЦІНКА РІВНЯ ЗАПАЛЬНИХ ПРОЦЕСІВ У ЩУРІВ ПРИ ЕКСПЕРИМЕНТАЛЬНОМУ КАНЦЕРОГЕНЕЗІ ТА ВПЛИВ НА НИХ ЕНТЕРОСОРБЦІї
}

Вступ. Проблема збільшення злоякісних пухлин товстої кишки - одна з найбільш актуальних у галузі медицини. Об'єктом уваги при вивченні канцерогенезу товстої кишки є стан імунної системи організму та активація запальних процесів в експериментальних тварин. Для нормалізації показників запалення перспективними є методи детоксикаційної терапії, а саме ентеросорбція.

Мета дослідження - оцінити рівень маркерів запалення в крові експериментальних тварин із хімічно індукованим канцерогенезом та їх динаміку при введенні вуглецевого ентеросорбенту АУТ.

Методи дослідження. Дослідження проводили на білих щурах-самцях. Тваринам моделювали рак товстої кишки шляхом введення 1,2-диметилгідразин гідрохлориду в дозі 7,2 мг/кг маси тіла протягом 30-ти тижнів. Ентеросорбент АУТ вводили інтрагастрально щоденно впродовж 21-ї доби після моделювання канцерогенезу в дозі 1 мл завису (що відповідає 0,2 г чистої маси препарату) на 100 г маси тіла тварини. Активність запальних процесів оцінювали за вмістом прозапального інтерлейкіну 6, протизапального інтерлейкіну 4 та С-реактивного протеїну в сироватці крові експериментальних тварин.

Результати й обговорення. Встановлено, що введення щурам 1,2-диметилгідразин гідрохлориду супроводжується зміною цитокінового профрілю та вмісту С-реактивного протеїну. В уражених тварин спостерігали збільшення вмісту прозапального інтерлейкіну 6 та С-реактивного протеїну, а також зменшення вмісту протизапального інтерлейкіну 4 в усі терміни дослідження. Застосування ентеросорбенту АУТ сприяло нормалізації цих показників.

Висновок. Отримані результати підтверджують позитивну динаміку використання детоксикаційної терапії сорбентом АУТ під час прогресуючого розвитку запальних процесів за умов змодельованого канцерогенезу.

КЛЮЧОВІ СЛОВА: запальні процеси; прозапальні інтерлейкіни; протизапальні інтерлейкіни; сорбент АУТ.

ВСТУП. Незважаючи на значний прогрес у лікуванні злоякісних пухлин товстої кишки, ця проблема залишається однією з головних у сучасній медицині. Об'єктом уваги при вивченні канцерогенезу товстої кишки є стан імунної системи організму.

Трансформація нормальної клітини в злоякісну супроводжується змінами всіх видів обміну речовин, насамперед протеїнового: в ядрі та цитоплазмі починається продукування специфрічних пухлинних антигенів, які експресуються на поверхні клітин, потрапляють у кров та стимулюють синтез антитіл імунною системою пухлиноносія [1, 2].

Під час динаміки пухлинного росту визначається рівновага між антибластомними фракторами імунного нагляду та пробластомними, які сприяють пухлинній прогресії. Останнім часом (с) О. І. Качур, Л. С. Фіра, П. Г. Лихацький, 2019. серед таких фракторів важливе місце посідають прозапальні (інтерлейкін 6 - ІЛ-6) та протизапальні (інтерлейкін 4 - ІЛ-4) цитокіни.

Науковці досліджують роль С-реактивного протеїну (СРП) у розвитку злоякісних пухлин. Вони відмічають, що С-реактивний протеїн $€$ маркером гострої фрази запалення та злоякісних пухлин [3]. Синтез СРП гострої фрази запалення запускається та регулюється насамперед цитокінами, а саме ІЛ-6, який утворюється безпосередньо у вогнищі запалення і виступає як первинний активатор генів, що вмикаються при ньому та пухлинній трансорормації.

Для нормалізації показників запалення перспективними є методи детоксикаційної терапії, а саме ентеросорбція. Лікувальний ефект сорбенту досягається за рахунок фрізико-хімічних властивостей сорбуючої речовини, здатної зв'язувати та виводити з організму токсичні про- 
дукти. Відомо, що вибір сорбенту з тією чи іншою пористою структурою дозволяє впливати на вибірковість сорбції токсинів і зумовлювати їх терапевтичний ефект.

Багаторічне вивчення медико-біологічних механізмів дії ентеросорбентів дало можливість дійти висновку, що на особливу увагу заслуговують вуглецеві ентеросорбенти, насамперед гранульовані, які складаються з вуглецевих волокон АУТ-М з питомою поверхнею пор близько 2000-2500 м²/г [4].

Мета дослідження - оцінити рівень маркерів запалення в крові експериментальних тварин із хімічно індукованим канцерогенезом та їх динаміку при введенні вуглецевого ентеросорбенту AУT.

МЕТОДИ ДОСЛІДЖЕННЯ. Дослідження проводили на 70 лабораторних білих щурах-самцях, яких утримували на стандартному раціоні віварію Тернопільського державного медичного університету імені І. Я. Горбачевського. Маса тіла тварин становила 180-220 г. Усі маніпуляції з експериментальними тваринами проводили, дотримуючись правил Європейської конвенції про захист хребетних тварин, що використовуються для дослідних та інших наукових цілей, а також відповідно до Науково-практичних рекомендацій з утримання лабораторних тварин та роботи з ними [5].

Щурів було поділено на 3 групи: 1-ша - контрольна; 2-га - тварини, уражені 1,2-диметилгідразин гідрохлоридом (ДМГ); 3-тя - тварини, уражені ДМГ, яким після 30-го тижня застосування канцерогену вводили ентеросорбент АУТ.

Рак товстої кишки моделювали шляхом введення несиметричного 1,2-диметилгідразин гідрохлориду (фрірми "SIGMA-ALDRICH CHEMIE", виробництва Японії), попередньо розведеного ізотонічним розчином натрію хлориду. Канцероген вводили підшкірно в міжлопаткову ділянку в дозі 7,2 мг/кг (з розрахунку на діючу речовину) 1 раз натиждень протягом 30-ти тижнів відповідно до маси тварини з розрахунку 0,1 мл розчину ДМГ на 100 г маси тіла щура. Сорбуючий препарат АУТ вводили інтрагастрально щоденно впродовж 21-ї доби після моделювання канцерогенезу. Добова доза сорбенту - 1 мл завису (що відповідає 0,2 г чистої маси препарату) на 100 г маси тіла тварини.

Кожного місяця від початку дослідження уражених тварин виводили з експерименту шляхом евтаназії під тіопенталовим наркозом. Для дослідження брали сироватку крові щурів.

Концентрацію про- та протизапальних інтерлейкінів у сироватці крові щурів визначали імунофрерментним методом за допомогою комерційних наборів ("GE Healthcare: Amersham", Велика Британія) [6]. Вміст С-реактивного протеїну визначали імунотурбідиметричним методом [7].

Отримані експериментальні дані статистично обробляли методом варіаційної статистики за допомогою стандартного пакета статистичної програми Statistica 6.0. Визначали середньоквадратичні відхилення, дисперсію та інші статистичні параметри, а розрахунки похибок вимірювання встановлювали при використанні t-критерію Стьюдента. Зміни вважали достовірними при $\mathrm{p} \leq 0,05$ [8].

РЕЗУЛЬТАТИ Й ОБГОВОРЕННЯ За УМОВ введення експериментальним тваринам канцерогену ДМГ організм реагував неспецифрічною запальною реакцією, яка проявлялася викидом цитокінів та підвищенням рівня СРП.

Цитокіни впливають практично на всі клітини, що беруть участь у розвитку запалення, включаючи гранулоцити, макрофраги, фрібробласти, клітини ендотелію та епітелію, Т- і В-лімсроцити [9, 10]. При запальному процесі цитокіни потрапляють у кров, що призводить до гострої відповіді на рівні всього організму.

За умов змодельованого патологічного процесу спостерігали суттєві порушення цитокінового профрілю, які характеризувалися зростанням вмісту прозапального цитокіну ІЛ-6. Так, цей показник підвищився на 1-й місяць ураження на 62,4 \% порівняно з тваринами інтактного контролю, після 30-тижневого ураження ДМГ вміст ІЛ-6 збільшився на 251 \% (табл. ).

Встановлено статистично достовірне зниження вмісту ІЛ-4 за умов прогресування запальних процесів, починаючи з 5-го місяця експерименту (на 41 \%). Даний показник зменшувався протягом наступних місяців дослідження (7-й місяць - на 80 \%) (табл.). Очевидно, це свідчить про виснаження протизапальних і антибластомних можливостей організмупухлиноносія на заключному етапі канцерогенезу, тому ІЛ-4 розглядають як прогностичний фрактор виникнення ускладнень [11].

Маркером системного запалення при індукованому канцерогенезі є С-реактивний протеїн. За умов ураження СРП синтезується переважно гепатоцитами під контролем прозапальних цитокінів [12-14]. Як показали результати дослідження, зростання ІЛ-6 спровокувало збільшення вмісту СРП. Так, досліджуваний показник на 3-й місяць моделювання канцерогенезу підвищився на 49 \%, на 7-й місяць - на 114 \% порівняно з контрольними значеннями (рис.). Отримані результати можуть свідчити про посилення запального процесу в організмі експериментальних тварин, уражених ДМГ. 
Таблиця - Вміст про- та протизапальних інтерлейкінів (пг/л) у сироватці крові щурів, уражених 1,2-диметилгідразин гідрохлоридом, та після застосування ентеросорбенту АУТ (M $\pm m, n=7)$

\begin{tabular}{|c|c|c|}
\hline Група тварин/місяць ураження & ІЛ-4 & ІІЛ-6 \\
\hline Контрольна група & $1,10 \pm 0,08$ & $1,97 \pm 0,12$ \\
\hline 1-й місяць & $1,04 \pm 0,08$ & $3,20 \pm 0,30^{*}$ \\
\hline 2-й місяць & $1,60 \pm 0,09$ & $3,09 \pm 0,27^{*}$ \\
\hline 3-й місяць & $0,98 \pm 0,08$ & $3,49 \pm 0,31^{*}$ \\
\hline 4-й місяць & $0,85 \pm 0,08$ & $4,07 \pm 0,36^{*}$ \\
\hline 5-й місяць & $0,78 \pm 0,07^{*}$ & $5,56 \pm 0,51^{*}$ \\
\hline 6-й місяць & $0,76 \pm 0,06^{*}$ & $6,65 \pm 0,60^{*}$ \\
\hline 7-й місяць & $0,61 \pm 0,05^{\star}$ & $6,92 \pm 0,62^{*}$ \\
\hline ДМГ+АУТ (14 днів) & $0,93 \pm 0,07^{\star *}$ & $4,20 \pm 0,33^{\star \star}$ \\
\hline ДМГ+АУТ (21 день) & $0,94 \pm 0,08^{\star *}$ & $3,60 \pm 0,26^{\star *}$ \\
\hline
\end{tabular}

Примітка. Тут і на рисунку: * - достовірні зміни між показниками тварин контрольної групи та щурів, уражених дмГ $(p \leq 0,05) ;$ ** - достовірні відмінності між показниками тварин, уражених ДМГ, і щурів, які отримували ентеросорбент АУТ $(\mathrm{p} \leq 0,05)$.

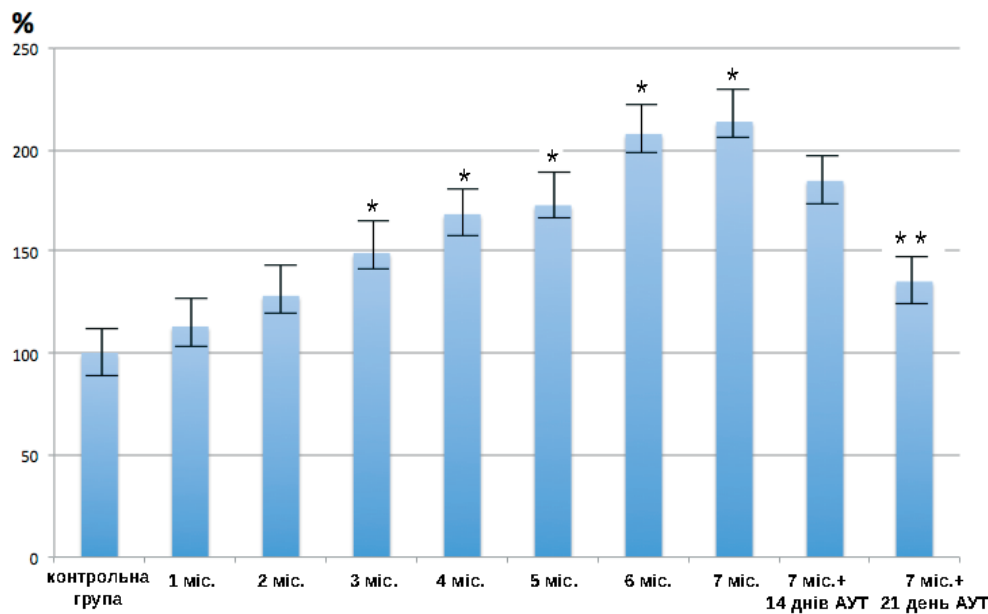

Рис. Вміст С-реактивного протеїну (\%) у сироватці крові щурів, уражених 1,2-диметилгідразин гідрохлоридом, та після застосування ентеросорбенту АУТ.

Застосування еферентної детоксикації за допомогою ентеросорбенту АУТ сприяло нормалізації у крові експериментальних тварин вмісту досліджуваних цитокінів та СРП. Так, вміст ІЛ-6 достовірно зменшився на 64 \% (14-та доба введення сорбенту) та $126 \%$ (21-ша доба) порівняно зі щурами, яким корекції не проводили. Позитивну динаміку відмічено ів збільшенні вмісту протизапального ІЛ-4, а саме на 14-ту добу застосування ентеросорбенту цей показник підвищився на 52 \%, на 21-шу добу - на $54 \%$. Аналогічно встановлено достовірне зниження вмісту СРП на 59 \% (21-ша доба детоксикаційної терапії).

Отже, 30-тижневе ураження щурів ДМГ викликало дисбаланс у вмісті про- та протизапальних цитокінів у сторону збільшення запальних процесів, що підтвердилося підвищенням вмісту в сироватці крові раннього маркера запалення С-реактивного протеїну. Застосування сорбційної терапії позитивно впливало на показники запалення в організмі щурів протягом усього експерименту.
ВИСНОВКИ. 1. Встановлено тривале підвищення рівня прозапального інтерлейкіну 6 на тлі зниження продукції протизапального інтерлейкіну 4, а також збільшення вмісту С-реактивного протеїну за умов 30-тижневого ураження щурів 1,2-диметилгідразин гідрохлоридом, що безпосередньо вказує на прогресування запальних процесів у організмі за індукованого канцерогенезу.

2. Після застосування детоксикаційної терапії вуглецевим сорбентом АУТ, завершення моделювання канцерогенезу спостерігають зниження активності запальних процесів у організмі щурів з експериментальним канцерогенезом. Це проявляється зменшенням вмісту прозапального інтерлейкіну 6 і С-реактивного протеїну та збільшенням вмісту протизапального інтерлейкіну 4.

3. Отримані результати дають можливість запропонувати включити вуглецеві ентеросорбенти у схеми лікування онкохворих 3 метою пригнічення запальних процесів та полегшення перебігу захворювання. 


\section{СПИСОК ЛІТЕРАТУРИ}

1. Бережная Н. М. Иммунология злокачественного роста / Н. М. Бережная, В. Ф. Чехун. - К. : Наукова думка, 2005. - 790 с.

2. Кармазіна І. С. Кореляційний аналіз показників білкового обміну при канцерогенезі та при запаленні / І. С. Кармазіна, В. А. Кулініч // Природничий альм. 2015. - № 12. - С. 112-118.

3. Андрейчин С. М. Зміни показників цитокінової ланки імунітету у хворих на ХОЗЛ при застосуванн ентеросорбції / С. М. Андрейчин, С. В. Лотоцька, В. М. Мерецький // Інфекційні хвороби. -2015. - № 3. C. 44-47.

4. Carbon adsorbents: achievements and perspectives / V. G. Nikolaev, L. A. Sakhno, E. A. Snezhkova [et al.] // Experimental Oncology. - 2011. - 33, No. 1. P. 2-8.

5. Gross D. Ethics in animal-based research / D. Gross, R. Tolba // Eur. Surg. Res. -2015. - 55 (1-2). P. 43-57.

6. Clinical significance of serum interleukin- 6 and $-174 \mathrm{G} / \mathrm{C}$ promoter polymorphism in Rheumatoid arthritis patients / W. Gaber, G. S. Azkalany, T. A. Gheita [et al.] // Egypt Rheumatol. - 2013. - 35 (2). - P. 107-113. doi:10.1016/j.ejr.12.11.002. [PubMed].

7. Анализ количественного определения уровня C-реактивного белка и прокальцитонина у пациентов с иноекционной патологией / К. М. Алибаева,

\section{REFERENCES}

1. Berezhnaya, N.M., \& Chekhun, V.F (2005). Immunologiya zlokachestvennogo rosta [Immunology of malignant growth]. Kyiv: Naukova dumka [in Russian].

2. Karmazina, I.S., \& Kulinich, V.A. (2015). Koreliatsiinyi analiz pokaznykiv bilkovoho obminu pry kantserohenezi ta pry zapalenni [Correlation analysis of protein metabolism indices at carcinogenesis and inflammation]. Pryrodnyi almanakh - Natural Almanac, 12, 112-118 [in Ukrainian].

3. Andreichyn, S.M., Lototska, S.V., \& Meretskyi, V.M. (2015). Zminy pokaznykiv tsytokinovoi lanky imunitetu u khvorykh na KhOZL pry zastosuvanni enterosorbtsii [Changes in the indices of cytokine immunity in patients with COPD when using enterosorption]. Infektsiini khvoroby - Infectious Diseases, 3, 44-47 [in Ukrainian].

4. Nikolaev, V.G., Sakhno, L.A., \& Snezhkova, E.A. (2015). Carbon adsorbents: achievements and perspectives. Experimental Oncology, 1, 2-8

5. Gross, D., \& Tolba, R. (2015). Ethics in aimal-based research. Eur. Surg. Res., 55 (1-2), 43-57.

6. Gaber, W., Azkalany, G.S., Gheita, T.A., Mohey, A., \& Sabry, R. (2013). Clinical significance of serum interleukin-6 and $-174 \mathrm{G} / \mathrm{C}$ promoter polymorphism in Rheumatoid arthritis patients. Egypt. Rheumatol.,35 (2), 107-113.

7. Alybaeva, K.M, Berdyyarova, N.A, Mukhamedzhanova, N.K, Maymakova, A.M., \& Nurakhova, A.D.
Н. А. Бердиярова, Н. К. Мухамеджанова [и др.] // Вестн. АГИУВ. - 2015. - № 1-2. - С. 36-40.

8. Okeh U. Statistical problems in medical research / U. Okeh // East. Afr. J. Public. Health. - 2009. - 6 (1). P. 1-7.

9. Нікітін $€$. В. Сучасні уявлення про систему цитокінів / Є. В. Нікітін, Т. Б. Чабан, С. К. Сервецький // Інфрекційні хвороби. - 2007. - № 2. - С. 64-69.

10. C-reactive protein, interleukin- 6 and the risk of colorectal cancer: a meta-analysis / B. Zhou, B. Shu, J. Yang [et al.] // Cancer Causes Control. - 2014. - 25 (10). - P. 1397-1405.

11. Васильева Г. И. Цитокины - общая система гомеостатической регуляции клеточных фрункций I Г.И.Васильева, И. А. Иванова, С. Ю. Тюкавкина // Цитология. - 2001. - 43, № 12. - С. 1101-1111.

12. C-reactive protein and the risk of incident colorectal cancer / T. Erlinger, E. Plaiz, N. Rifai, K. Helzlsouer // JAMA. - 2004. - 291, No. 5. - P. 585-590.

13. Zhang $X$. Circulating levels of $C$-reactive protein, interleukin- 6 and tumor necrosis factor- $\alpha$ and risk of colorectal adenomas: a meta-analysis / X. Zhang, S. Liu, Y. Zhou // Oncotarget. - 2016. - 27, 7 (39). P. 64371-64379.

14. Markers of systemic inflammation and colorectal adenoma risk: Meta-analysis of observational studies / J. Godos, A. Biondi, F. Galvano [et al.] // World J. Gastroenterol. - 2017. - 23 (10). - P. 1909-1919.

(2015). Analiz kolichestvennogo opredeleniya urovnya S-reaktyvnogo belka i prokaltsytonina u patsyyentov s infektsyonnoy patologiyey [Analysis of the quantitative determination of the level of $\mathrm{C}$-reactive protein and procalcitonin in patients with infectious diseases]. Vestnyk AHYUV - Bulletin of AGIUV, 1-2, 36-40 [in Russian].

8. Okeh, U.(2009). Statistical problems in medical research. East. Afr. J. Public. Health, 6 (1), 1-7.

9. Nikitin, Ye.V., Chaban, T.B., \& Servetskyi, S.K. (2007). Suchasni uiavlennia pro systemu tsytokiniv [Contemporary notions about the system of cytokines]. Infektsiini khvoroby - Infectious Diseases 2, 64-69 [in Ukrainian].

10. Zhou, B., Shu, B., Yang, J., Liu, J., Xi, T., \& Xing, Y. (2014). C-reactive protein, interleukin- 6 and the risk of colorectal cancer: a meta-analysis. Cancer Causes Control, 25 (10), 1397-1405.

11. Vasyleva, G.I., Ivanova, I.A., \& Tyukavkina, S.Yu. (2001). Tsytokiny-obshchaya sistema gomeostaticheskoy regulyatsii kletochnykh funktsyy [Cytokines - general system of homeostatic regulation of cellular functions]. Tsytologiya - Cytology, 43 (12), 1101-1111 [in Ukrainian].

12. Erlinger,T., Plaiz, E., Rifai, N., \& Helzlsouer, K. (2004) C-reactive protein and the risk of incident colorectal cancer. JAMA, 5, 585-590.

13. Zhang, X., Liu, S., \& Zhou, Y. (2016). Circulating levels of C-reactive protein, interleukin- 6 and tumor 
necrosis factor- $\alpha$ and risk of colorectal adenomas: a meta-analysis. Oncotarget, 27, 7 (39), 64371-64379

14. Godos, J., Biondi, A., Galvano, F., Basile, F. Sciacca, S., Giovannucci, E.L., \& Grosso, G. (2017).
Markers of systemic inflammation and colorectal adenoma risk: Meta-analysis of observational studies. World J. Gastroenterol., 23 (10), 1909-1919.

О. И. Качур, Л. С. Фира, П. Г. Лихацкий ТЕРНОПОЛЬСКИЙ ГОСУДАРСТВЕННЫЙ МЕДИЦИНСКИЙ УНИВЕРСИТЕТ ИМЕНИ И. Я. ГОРБАЧЕВСКОГО

\section{ОЦЕНКА УРОВНЯ ВОСПАЛИТЕЛЬНЫХ ПРОЦЕССОВ У КРЫС ПРИ ЭКСПЕРИМЕНТАЛЬНОМ КАНЦЕРОГЕНЕЗЕ И ВЛИЯНИЕ НА НИХ ЭНТЕРОСОРБЦИИ}

\section{Резюме}

Вступление. Проблема увеличения злокачественных опухолей толстой кишки - одна из наиболее актуальных в области медицины. Объектом внимания при изучении канцерогенеза толстой кишки являются состояние иммунной системы организма и активация воспалительных процессов у экспериментальных животных. Для нормализации показателей воспаления перспективными являются методы детоксикационной терапии, а именно энтеросорбция.

Цель исследования - оценить уровень маркеров воспаления в крови экспериментальных животных с химически индуцированным канцерогенезом и их динамику при введении углеродного энтеросорбента AYT.

Методы исследования. Исследование проводили на белых крысах-самцах. Животным моделировали рак толстой кишки путем введения 1,2-диметилгидразин гидрохлорида в дозе 7,2 мг/ка массы тела на протяжении 30-ти недель. Энтеросорбент АУТ вводили интрагастрально ежедневно в течение 21-х суток после моделирования канцерогенеза в дозе 1 мл взвеси (что соответствует 0,2 г чистой массы препарата) на 100 г массы тела животного. Активность воспалительных процессов оценивали по содержанию провоспалительного интерлейкина 6, противовоспалительного интерлейкина 4 и С-реактивного протеина в сыворотке крови экспериментальных животных.

Результаты и обсуждение. Установлено, что введение крысам 1,2-диметилгидразин гидрохлорида сопровождается изменением цитокинового профиля и содержания С-реактивного протеина. У пораженных животных наблюдали увеличение содержания провоспалительного интерлейкина 6 и С-реактивного протеина, а также уменьшение содержания противовоспалительного интерлейкина 4 во все сроки исследования. Применение энтеросорбента АУТ способствовало нормализации этих показателей.

Вывод. Полученные результаты подтверждают положительную динамику использования детоксикационной терапии сорбентом АУТ во время прогрессирующего развития воспалительных процессов в условиях смоделированного канцерогенеза.

КЛЮЧЕВЫЕ СЛОВА: воспалительные процессы; провоспалительные интерлейкины; противовоспалительные интерлейкины; сорбент АУТ.

\section{EVALUATION OF INFLAMMATORY PROCESS LEVEL IN RATS AT EXPERIMENTAL CARCINOGENESIS AND EFFECT OF ENTEROSORPTION ON THEM}

\section{Summary}

Introduction. The problem of increasing malignant tumors of the colon is one of the most urgent in the field of medicine. The object of attention in the study of carcinogenesis of the large intestine is the state of the immune system of the organism and the activation of inflammatory processes in experimental animals. For the normalization of indicators of inflammation, methods of detoxification therapy are promising, namely enterosorption. 
The aim of the study - to evaluate changes in the level of markers of inflammation in the blood of experimental animals with chemically induced carcinogenesis and the dynamics of their changes when introducing a carbon enterosorbent AUT.

Research Methods. The studies were conducted on white male rats. Animals were modeled colon cancer by administering 1,2=dimethylhydrazine hydrochloride at a dose of $7.2 \mathrm{mg} / \mathrm{kg}$ of body weight for 30 weeks. Enterosorbent AUT was injected intragastrally daily for 21 days after the carcinogenesis modeling in a dose of $1 \mathrm{ml}$ of curd (corresponding to $0.2 \mathrm{~g}$ of pure weight of the drug) per $100 \mathrm{~g}$ of animal body weight. The activity of inflammatory processes was assessed by concentration of proinflammatory interleukin-6, interleukin 4 and C-reactive protein in the blood serum of experimental animals.

Results and Discussion. It was established that the administration of 1.2 dimethylhydrazine hydrochloride to animals is accompanied by a change in the cytokine profile and the content of C-reactive protein. There was an increase in pro-inflammatory interleukin 6, a decrease in anti-inflammatory interleukin 4 and an increase in the content of C-reactive protein in all terms of the study. The use of an enterosorbent AUT improved the results.

Conclusion. The obtained results confirm the positive dynamics of the use of detoxification therapy with sorbent AUT during the progressive development of inflammatory processes in conditions of simulated carcinogenesis.

KEY WORDS: inflammatory processes; proinflammatory interleukins; anti-inflammatory interleukins; sorbent AUT.

Отримано 12.04.19

Адреса для листування: Л. С. Фіра, Тернопільський державний медичний університет імені І. Я. Горбачевського, майдан Волі, 1, Тернопіль, 46001, Україна, e-mail: firals@tdmu.edu.ua. 